\title{
Upaya Peningkatan Hasil Belajar Matematika Menggunakan Model Pembelajaran Kooperatif Tipe STAD pada Materi Bangun Ruang Sisi Datar
}

\author{
Yuliana Priatina \\ SMP Islam Terpadu At-Taufiq
}

\section{INFO ARTICLES}

Article History:

Received: 08-12-2018

Revised: 14-12-2018

Approved: 27-12-2018

Publish Online: 30-12-2018

KeyWords:

Mathematics learning outcome, STAD Type Cooperative Learning Model,construct flat side space.

\section{(c) (i) (?)}

This article is licensed

under a Creative Commons AttributionShareAlike 4.0 International License.

\begin{abstract}
The purpose of this research is to increase students mathematics learning outcomes through the STAD type cooperative method. This research was carried out in class VIII A SMP Islam Terpadu At-Taufiq on material to construct flat side space.The method used is action research or class action. Sample taken were 25 students.
\end{abstract}

\begin{abstract}
Abstrak: Penelitian ini bertujuan untuk meningkatkan hasil belajar matematika siswa melalui metode kooperatif tipe STAD. Penelitian ini dilakukan di kelas VIII A SMP Islam Terpadu At-Taufiq pada materi bangun ruang sisi datar. Metode yang digunakan adalah action research atau tindakan kelas. Sampel yang diambil sejumlah 25 siswa.
\end{abstract}

Correspondence Address:Jl. Putri Tunggal No.17, Harjamukti, Cimanggis, Depok, Jawa Barat, 16454, Indonesia; e-mail: yulialkarim@gmail.com

How to Cite (APA $6^{\text {th }}$ Style): Priatina. (2018). Upaya Peningkatan Hasil Belajar Matematika Menggunakan Model Pembelajaran Kooperatif Tipe STAD pada Materi Bangun Ruang Sisi Datar. JKPM (Jurnal Kajian Pendidikan Matematika), Vol.4 (1), 67-78.

Copyright:Yuliana Priatina, (2018)

Competing Interests Disclosures: The authors declare that they have no significant competing financial, professional or personal interests that might have influenced the performance or presentation of the work described in this manuscript. 


\section{PENDAHULUAN}

Pendidikan adalah suatu hal mutlak yang harus dipenuhi dalam upaya untuk meningkatkan taraf hidup bangsa agar tidak sampai tertinggal dengan bangsa lain, sebab dari pendidikan inilah nanti akan lahir generasi-generasi penerus bangsa. Dalam UU. No. 20 tahun 2003 tentang Sistem Pendidikan Nasional (Sisdiknas) Bab I pasal 1 menyebutkan bahwa:

"Pendidikan adalah usaha sadar dan terencana untuk mewujutkan suasana belajar dan proses pembelajaran agar peserta didik secara aktif mengembangkan potensi dirinya untuk memiliki kekuatan spiritual keagamaan, pengendalian diri, kepribadian, kecerdasan, akhlak mulia, serta keterampilan yang diperlukan dirinya, masyarakat, bangsa dan negara"(Undang-undang RI No.20 Tahun 2003, Grafida:2009).

Sebagaimana tercantum dalam pembukaan UUD 1945 alinea ke IV bahwasanya salah satu tujuan dari terbentuknya Negara Indonesia adalah mencerdaskan kehidupan bangsa. Berdasarkan tujuan di atas maka dalam usaha mencerdaskan kehidupan bangsa dan membentuk generasi muda yang berakhlak mulia yang nantinya dapat membawa kemajuan bangsa, maka pelaksanaan pendidikan sangat diperlukan terutama dalam meningkatkan mutu kualitasnya, sehingga dapat berperan aktif dalam pembangunan bangsa.

Atas dasar itu jelaslah bahwa pendidikan merupakan tanggung jawab bersama baik pemerintah dan masyarakat sekitar. Sedangkan inti kegiatan suatu sekolah atau kelas adalah proses belajar mengajar, kualitas belajar siswa serta para lulusan banyak ditentukan oleh keberhasilan pelaksanaan proses belajar mengajar tersebut. Atau dengan kata lain, kualitas belajar mengajar banyak ditentukan oleh fungsi dan peran para guru.

Proses pembelajaran di kelas memiliki peranan yang sangat penting dalam upaya pencapaian tujuan pembelajaran. Guru hendaknya dapat memilih dan menentukan metode pembelajaran yang sesuai dengan materi atau bahan ajar yang akan diberikan pada siswa. Pemilihan dan penentuan metode pembelajaran yang sesuai dengan karakteristik materi atau bahan ajar yang akan diajarkan diharapkan dapat memudahkan siswa untuk memahami materi yang diajarkan dan pembelajaran menjadi lebih menyenangkan bagi siswa.

Matematika sebagai ilmu dasar, dewasa ini telah berkembang dengan sangat pesat, baik materi maupun kegunaannya, sehingga dalam pembelajarannya di sekolah kita harus memperhatikan perkembangannya, baik di masa lalu, masa sekarang maupun untuk masa depan (Erman, 2003).

Sebagaimana kita ketahui bahwa kemampuan antara siswa satu dengan siswa yang lain itu berbedabeda, hal itulah yang menyebabkan daya penguasaan siswa akan materi yang diajarkan juga berbeda-beda. Untuk itu diperlukan metode belajar yang dapat menanamkan pemahaman konsep dasar para siswa sebagai acuan dalam memahami konsep selanjutnya.

Salah satu model yang dapat diterapkan pada pembelajaran matematika dan yang berkembang saat ini adalah model pembelajaran kooperatif. Keuntungan dari pembelajaran kooperatif antara lain: 1) Dapat meningkatkan kecakapan individu maupun kelompok dalam memecahkan masalah, 2) Meningkatkan komitmen, 3) Menghilangkan prasangka buruk terhadap teman sebaya, 4) Tidak memiliki rasa dendam. Pembelajaran kooperatif dalam prakteknya adalah salah satu bentuk pembelajaran yang berdasarkan faham kontruktivistik atau membangun sendiri pengetahuan mereka. Disini meskipun pada dasarnya pengetahuan telah terbangun oleh orang lain tetapi siswa diajak membangun kembali pengetahuan yang akan dipelajari.

Alasan pemilihan model pembelajaran kooperatif tipe STAD dalam penelitian ini karena tipe STAD mengajarkan siswa lebih aktif dalam proses belajar mengajar dan dapat berorganisasi serta bertukar pikiran 
untuk memecahkan masalah. Dalam penelitian ini memfokuskan mata pelajaran matematika materi bangun datar karena pada materi ini siswa dirasa kurang dalam pemahaman materi, sehingga hasil belajar belum memenuhi standar yang ditentukaan. Materi ini dianggap sulit oleh siswa sehingga membutuhkan inovasi model-model pembelajaran yang digunakan dalam menyampaikan materi. Sehingga dapat mempermudah siswa dalam memahami materi yang disampaikan guru.

Berdasarkan atas rumusan masalah di atas, maka tujuan dilaksanakan penelitian ini adalah untuk mengetahui penerapan model pembelajaran kooperatif tipe STAD (Student Teams Achievement Divisions) mampu meningkatkan hasil belajar siswa kelas VIII A SMP Islam Terpadu At-Taufiq, mengetahui hasil belajar siswa kelas VIII A SMP Islam Terpadu At-Taufiq saat mengikuti mata pelajaran matematika dan juga untuk mengetahui model pembelajaran kooperatif tipe STAD (Student TeamsAchievement Divisions) dapat meningkatkan hasil belajar siswa kelas VIII A SMP Islam Terpadu At-Taufiq.

\section{METODE}

Subjek penelitian ini adalah siswa kelas VIII A SMP Islam Terpadu At-Taufiq kota Depok yang berjunlah 25 siswa. Teknik pengumpulan data dalam penelitian ini menjadi unsur yang sangat penting. Maka teknik pengumpulan data dalam penelitian ini antara lain sebagai berikut: tes, observasi, wawancara, catatan lapangan, sedangkan pendukung dari Teknik pengumpulan data dalam penelitian ini menjadi unsur yang sangat penting. Maka teknik pengumpulan data dalam penelitian ini antara lain sebagai berikut: tes, observasi, wawancara, catatan lapangan, sedangkan pendukung dari teknik ini adalah dokumentasi.

Tes yang digunakan pada penelitian ini berupa soal uraian yang dilaksanakan pada saat pra tindakan (pre test) maupun pada akhir tindakan (post test) yang nantinya hasil tes ini akan diolah untuk mengetahui tingakat keberhasilan siswa dalam proses model pembelajaran kooperatif tipe STAD pada mata pelajaran matematika.

Kriteria penilaian dari hasil tes ini adalah sebagai berikut :

Untuk menghitung hasil tes, baik pre test maupun post test pada proses pembelajaran dengan menggunakan model pembelajaran kooperatif tipe STAD, digunakan rumus percentages correction sebagai berikut ini (Purwanto, 2004:102):

$$
\mathrm{NP}=\frac{R}{S M} \mathrm{X} 100 \%
$$

Keterangan:

NP : Nilai yang dicari atau diharapkan

$\mathrm{R} \quad$ : Skor mentah yang diperoleh siswa

SM : Skor maksimum ideal dari tes yang bersangkutan

100 : Bilangan tetap

Dalam Penelitian Tindakan Kelas ini proses analisis data dimulai dengan menelaah seluruh data yang tersedia dari berbagai sumber, yaitu dari wawancara, observasi (pengamatan) yang sudah ditulis dalam sebuah catatan lapangan dan dokumen lainnya.

Beranjak dari pendapat di atas, maka penelitian ini menggunakan analisis data kualitatif model mengalir dari Miles dan Huberman yang meliputi 3 hal yaitu:

1. Reduksi data (Data Reduction) 
2. Penyajian data (Data Dispaly)

3. Penarikan kesimpulan (Condusion Drawing)

Model penelitian yang digunakan adalah model Kemmis dan Mc.Taggart, yaitu model spiral. Dimana dalam model spiral ini terdiri dari 2 siklus dan dari setiap siklus terdiri dari perencanaan, pelaksanaan tindakan, observasi serta refleksi.

Tahapan-tahapan dalam penelitian tindakan ini mencangkup:

1. Pra Tindakan

a. berdiskusi baik dengan guru mata pelajaran matematika kelas VIIIA maupun kepala sekolah.

b. Peneliti membuat soal tes awal (pre test)

c. Pelaksanaan pre tes

d. Evaluasi

2. Siklus I
a. Perencanaan
b. Pelaksanaan Tindakan
c. Observasi
d. Refleksi

3. Siklus II
a. Perencanaan
b. Pelaksanaan Tindakan
c. Observasi
d. Refleksi

\section{HASIL}

Penelitian diawali dengan tes awal (pre test) yang diikuti oleh seluruh siswa yakni 25 siswa, dengan hasil rata-rata 60,1. Siswa yang tuntas belajar hanya ada 6 siswa dari 25 siswa. Nilai tes awal tersebut dilihat pada tabel berikut:

$$
\mathrm{NP}=\frac{\mathrm{R}}{\mathrm{SM}} \times 100=\frac{1502}{2500} \times 100=60,1
$$

Keterangan :

T : Tuntas

TT : Tidak Tuntas

Dari hasil diatas, dapat diketahui bahwa siswa kurang menguasai materibangun ruang sisi datar. Ini terbukti dengan jumlah nilai rata-rata/ NP pre test siswa adalah 60,1. Siswa yang tuntas belajar hanya ada 6 siswa dari 25 siswa. Siklus 1 rata-rata 72,56 dengan 15 siswa yang tuntas, dan siklus 2 dengan rata-rata 86,96 dengan menyisakan 6 siswa yang tidak tuntas Siswa banyak melakukan kesalahan dalam menjawab soal sehingga disimpulkan bahwa siswa belum sepenuhnya mengetahui apa itu bangun ruang sisi datar.

Selanjutnya peneliti membentuk kelompok berdasarkan hasil pre test. Ada lima kelompok yang berhasil dibentuk dan setiap kelompok terdiri dari lima orang anggota. Hasil pembagian kelompok tadi akan dibacakan pada pertemuan berikutnya (siklus I). 


\section{PEMBAHASAN}

\section{Paparan Data Pelaksanaan Tindakan Siklus I}

a. Tahap Perencanaan Tindakan I

Pada tahap ini kegiatan yang dilakukan oleh peneliti adalah sebagai berikut:

1) Menyusun rencana pelaksanaan pembelajaran (RPP)

2) Menyiapkan materi pembelajaran yang akan disajikan yaitu tentangbangun ruang sisi datar

3) Menyiapkan alat peraga/ media

4) Menyusun lembar observasi

5) Menyiapkan soal tes untuk siswa yaitu tes kelompok, tes individu (tes akhir siklus I), dan kuis

6) Menyiapkan media penghargaan

7) Melakukan koordinasi dengan teman sejawat mengenai pelaksanaan tindakan kelas

b. Tahap Pelaksanaan Tindakan I

Siklus I dilaksanakan dalam 2 pertemuan (6 jam pelajaran), dengan alokasi waktu 1 jam pelajaran adalah 40 menit. Secara lebih rinci, masing-masing tahapan dapat dijelaskan sebagai berikut:

1) Pertemuan Pertama

Dilaksanakan pada hari Selasa 15 Mei 2012 dengan alokasi waktu 3 x 40 menit. Pada pertemuan pertama ini kegiatan pembelajaran disesuaikan dengan RPP yang terdiri dari tiga tahap yang akan dijelaskan masing-masing tahapannya.

a) Kegiatan Awal

Peneliti memulai pelajaran dengan mengucapkan salam dan mempresensi siswa. Selanjutnya peneliti menyampaikan tujuan pembelajaran hari ini dan menyampaikan tentang model pembelajaran yang akan diterapkan yaitu model pembelajaran kooperatif tipe STAD (Student Teams Achievement Division), serta melakukan apersepsi sebagai gambaran pengetahuan awal mengenai materi yang akan disampaikan yaitu bangun ruang sisi datar.

b) Kegiatan Inti

Sebagai kegiatan inti dari model pembelajaran kooperatif tipe STAD (Student Teams Achievement Divisions), Peneliti mencoba menarik perhatian siswa dengan memberikan pertanyaan yang bertujuan agar siswa dapat memperhatikan apa yang dijelaskan. Adapun pertanyaan yang dimaksud "Apakah ciri-ciri bangun ruang sisi datar yang simetri?" Selanjuntnya ada tiga orang siswa yang aktif memberikan tanggapan walaupun dengan jawaban yang sama. Sedangkan siswa yang lain perlahan-lahan mulai mulai fokus mengikuti pelajaran dan memperhatikan. Dalam hal ini, peneliti sedapatnya memberikan arahan, motivasi, serta penguatan bagi siswa yang masih pasif dalam pembelajaran dan menekankan kembali agar tidak ragu atau malu dalam mengemukakan pendapat.

Setelah peneliti selesai menyampaikan materi, selanjutnya peneliti membacakan kelompok belajar. Siswa dibagi menjadi 5 kelompok dimana masing-masing kelompok beranggotakan 5 orang siswa yang dibentuk berdasarkan hasil pre test sebelumnya. 
Kemudian guru membagikan lembar kerja dan mediabangun ruang sisi datar yang bisa dimanfaatkan untuk menyelesaikan soal pada lembar kerja tersebut. Siswa dijelaskan tentang aturan main model pembelajaran kooperatif tipe STAD yaitu:

- Setiap anggota kelompok harus berbagi gagasan dan pengalaman untuk memecahkan masalah soal yang dihadapi

- Semua anggota dalam kelompok mempunyai tanggung jawab yang sama karena nanti akan diminta perwakilan kelompok secara acak untuk mempresentasikan di depan kelas dan kelompok lain menanggapinya

- Harus menghargai pendapat orang lain

- Setiap anggota kelompok harus saling membentu jika menghadapi masalah soal sebelum meminta pertolongan peneliti

- Permasalahan diselesaikan dengan cara dianalisis terlebih dahulu dan menentukan jawaban sementara kemudian diuji kebenarannya dengan menggunakan alat peraga sehingga bisa ditarik kesimpulan

- Masing-masing kelompok dilarang mengganggu jalannya diskusi kelompok lain

Berdasarkan pengamatan, secara keseluruhan terlihat sebagian besar anggota kelompok belum dapat bekerjasama dengan baik karena masih ada beberapa siswa yang individualis, pasif, dan ramai sendiri. Menghadapi hal seperti ini, peneliti mendekati kelompok tersebut kemudian memberikan arahan agar dapat bekerjasama dengan kelompoknya. Waktu yang dibutuhkan semua kelompok untuk berdiskusi adalah 40 menit.

c) Kegiatan Akhir

Setelah waktu mengerjakan habis, siswa diminta kembali ke tempat semula dan mengumpulkan lembar jawabannya. Guru mengakhiri pertemuan dengan salam dan mengingatkan siswa bahwa pertemuan besok akan diadakan presentasi terhadap hasil kerja yang akan dilakukan oleh perwakilan kelompok yang dipilih secara acak. Oleh sebab itu, siswa harus mempersiapkan diri di rumah.

2) Pertemuan Kedua

Pertemuan kedua dilaksanakan pada hari Selasa tanggal 22 Mei 2012 karena hari Kamis libur tanggal merah. Kegiatan sesuai RPP yang telah dibuat yang terdiri dari tiga tahap:

a) Kegiatan Awal

Guru memberi salam kemudian melakukan apsensi siswa dan mengingatkan kembali tujuan pembelajaran yang harus dicapai.

b) Kegiatan Inti

Pada kegiatan inti guru menugaskan siswa untuk berkumpul dengan kelompoknya dan membagikan lembar jawaban siswa. Guru menunjuk perwakilan kelompok yang dipilih secara acak untuk menjelaskan/ mempresentasikan hasil jawaban kelompoknya di depan kelas. Pada kesempatan kali ini yang ditunjuk adalah kelompok dua. Setelah selesai menjelaskan, kelompok lain diberi kesempatan untuk menanggapi atau bertanya kepada kelompoknya. Namu kelompok lain masih pasif, sehingga guru memberikan arahan agar menanggapi presentasi kelompok dua, misalnya dengan menunjukkan jawaban yang berbeda. Akhirnya kelompok satu memberi tanggapan tentang jawaban soal nomor 5. Yang menyimpulkan bahwa hasil jawaban kelompok dua salah karena terbalik dalam 
menempatkan huruf pada tiap sudutnya. Kelompok lain juga ikut menanggapi hal itu. Kegiatan dipandu oleh guru dan presentasi diakhiri dengan penjelasan dari guru.

c) Kegiatan Akhir

Kegiatan akhir, guru memberikan soal tulis secara individu (tes akhir tindakan) untuk mengetahui tingkat pemahaman masing-masing siswa dan setelah selesai siswa diminta mengumpulkan lembar jawabannya dan kembali ke tempat duduk masing-masing. Guru memberikan evaluasi dan memberikan bintang penghargaan kepada kelompok dan siswa yang mendapat nilai tertinggi. Kemudian guru dan siswa membuat kesimpulan tentang pelajaran hari ini serta memberitahukan bahwa pertemuan Kamis depan akan dilaksanakan siklus II untuk memperbaiki nilai yang kurang baik dan melanjutkan indikator yang belum selesai. Kegiatan diakhiri dengan salam dan pemberian kuis, bagi yang bisa menjawab bisa pulang terlebih dahulu.

c. Hasil Observasi

Pengamatan dilakukan oleh dua pengamat, yaitu ibu Nurhayati, S.Pd sebagai pengamat 1 (guru mata pelajaran matematika kelas VIIIA) dan bapak Subur Kasih sebagai pengamat 2 (teman sejawat dari SMP Islam Terpadu At-Taufiq). Pengamat 1 bertugas mengamati semua aktivitas guru (peneliti) dan pengamat 2 bertugas mengamati aktivitas siswa selama pembelajaran berlangsung. Pengamatan ini dilakukan sesuai pedoman yang telah disediakan peneliti.

Skor yang diperoleh dari pengamatan tentang aktivitas guru adalah 42, sedangkan skor maksimal adalah 50. Sehingga skor yang diperoleh rata-rata adalah

$\frac{42}{50} \times 100 \%=84 \%$.

Maka taraf keberhasilan aktivitas peneliti berada pada kategori baik.Sementara itu, hasil pengamatan yang dilakukan oleh pengamat kedua terhadap aktivitas siswa selama kegiatan pembelajaran dapat dilakukan pada tabel berikut:

Secara umum kegiatan siswa belum sesuai harapan karena masih banyak descriptor yang tidak muncul dalam aktivitas siswa selama pembelajaran. skor yang diperoleh tentang aktivitas siswa adalah 36 , sedangkan skor maksimal adalah 50 . Sehingga skor yang diperoleh rata-rata adalah $\frac{36}{50} \mathrm{x}$ $100 \%=72 \%$

'Sesuai taraf keberhasilan yang telah ditetapkan maka taraf keberhasilan aktivitas siswa berada pada kategori cukup.

d. Hasil Catatan Lapangan

Beberapa hal yang sempat dicatat peneliti dan dua pengamat adalah sebagai berikut:

1) Pada waktu pembelajaran dimulai, masih terdapat beberapa siswa yang ramai dan berbicara dengan temannya serta tidak menghiraukan penjelasan guru sehingga peneliti harus lebih memperhatikan pengelolaan kelas

2) Banyak siswa yang masih mengandalkan jawaban temannya dan ada juga yang memilih untuk bergabung dengan kelompok lain yang dianggap mempunyai kesesuaian misal dalam bentuk ide atau sikap

3) Beberapa siswa lebih senang langsung bertanya kepada peneliti atau guru dari pada berdiskusi dengan teman dalam kelompoknya

4) Banyak siswa yang menggunakan media sebagai bahan mainan, tidak untuk menyelesaikan soal 
5) Beberapa siswa terlihat kurang siap dan tegang saat proses pembelajaran karena siswa perlu beradaptasi terlebih dahulu dengan metode dan guru baru

e. Hasil Tes Siswa

Berdasarkan hasil tes terakhir (pos tes) pada siklus I diurutkan berdasarkan urutan jumlah nilai tertinggi ke nilai terendah yang akan dapat dilihat pada tabel berikut:

$$
\mathrm{NP}=\frac{\mathrm{R}}{\mathrm{SM}} \mathrm{X} 100=\frac{1814}{2500} \mathrm{X} 100=72,56
$$

Berdasarkan hasil tes akhir siklus I menunjukkan bahwa hasil tes siswa berkriteria cukup dan terjadi peningkatan pemahaman pada siswa. Hal ini dibuktikan dengan nilai rata-rata pre test adalah 60,1 sedangkan rata-rata skor tes akhir siklus I adalah 72,56. Sedangkan siswa yang berada pada taraf tuntas adalah 15 siswa dari 25 dan pada pre test yang mencapai kategori tuntas hanya 6 siswa dari 25 siswa.

Berdasarkan nilai akhir siklus I ini akan digunakan sebagai acuan dalam pemberian penghargaan kelompok. Poin peningkatan individual diperoleh dari poin yang dikumpulkan berdasarkan nilai tes awal dan nilai tes siklus I,

Setelah diperoleh hasil tes dihitung skor peningkatan individual berdasarkan perolehan nilai tes awal dengan nilai tes akhir pada siklus I. berdasarkan skor peningkatan individual dihitung skor perbaikan (skor perkembangan)ada 16 siswa yang mendapat skor perbaikan 30; 5 siswa memperoleh skor perbaikan 20 dan 4 siswa memperoleh skor perbaikan 10. Untuk penghargaan kelompok (tim), kelompok I dan II memperoleh penghargaan sebagai kelompok (tim) hebat dan kelompok III, IV dan V memperoleh penghargaan sebagai kelompok (tim) super.

f. Refleksi

Berdasarkan kegiatan analisis dan diskusi dengan teman sejawat terhadap hasil tes akhir dan hasil pengamatan pada siklus I, maka dapat diperoleh beberapa hal sebagai berikut:

1) Hasil belajar siswa berdasarkan nilai tes kelompok menunjukkan nilai yang sangat baik tetapi siswa mengerakkan secara maksimal karena masih mengandalkan jawaban dari teman kelompoknya sehingga ketika mengerjaka soal individu masih banyak siswa yang mendapatkan nilai dibawah rata-rata.

2) Hasil belajar siswa berdasarkan nilai tes akhir siklus I menunjukkan peningkatan yang lebih baik dari pada tes sebelumnya. Hal ini menunjukkan bahawa pemahaman siswa terhadap materi pelajaran semakin meningkat.

3) Aktivitas siswa telah menunjukkan tingkat keberhasilan pada kriteria cukup.

4) Kegiatan pembelajaran menunjukkan penggunaan waktu yang sudah sesuai rencana, sehingga tidak diperlikan pengulangan siklus untuk mengatur waktu.

5) Akan tetapi perlu dilakukan siklus I karena rata-rata skor belum mencapai target standar KKM. Target siswa tuntas pada penelitian ini adalah $75 \%$. Serta dalam proses pembelajaran secara kelompok diketahui masih banyak siswa yang bekerja tidak maksimal. Banyak yang gaduh sendiri dan mengandalkan hasil jawaban teman kelompoknya. Hal ini dikarenakan siswa belum bisa beradaptasi dengan tipe STAD yang digunakan oleh peneliti. Jadi jelas perlu dilakukan siklus II untuk meningkatkan aktivitas dan hasil belajar siswa.

\section{Paparan Data Pelaksanaan Tindakan Siklus II}

a. Tahap Perencanaan 
Pada tahap ini kegiatan yang dilakukan oleh peneliti adalah sebagai berikut:

1) Membuat RPP yang disesuaikan dengan hasil refleksi siklus I

2) Menyiapkan media yang dibutuhkan

3) Membuat lembar kegiatan siswa yang berupa lembar kerja kelompok, lembar kerja individu untuk tes akhir tindakan siklus I, dan soal kuis

4) Menyiapkan lembar observasi

5) Menyiapkan media penghargaan

6) Melakukan koordinasi dengan teman sejawat mengenai pelaksanaan tindakan kelas

b. Pelaksanaan Tindakan

Tindakan pada siklus II ini dilaksanakan dalam tiga pertemuan sebagai berikut:

1) Pertemuan pertama siklus II

Pelaksanaan tindakan pada pertemuan pertama siklus II ini dilaksanakan pada hari Kamis 24 Mei 2012.

a) Kegiatan Awal

Guru melakukan aktivitas sehari hari seperti mengucap salam, absensi siswa, membecakan tujuan pembelajaran, menyampaikan model pembelajaran kooperatif tipe STAD (Student Teams Achievement Division), dan melakukan apersepsi.

b) Kegiatan Inti

Kegiatan inti dimulai dengan penjelasan guru tentang materi secara garis besar, kemudian guru menugaskan siswa berkumpul dengan kelompoknya (anggota kelompok yang tetap seperti pertemuan sebelumnya). Guru memberikan mediabangun ruang sisi datar dan membuat kelompoknya selama 40 menit. Kegiatan pembelajaran pada siklus II ini sudah lebih baik dibandingkan dengan tugas masing-masing, hal ini terlihat denganadanya partisipasi semua siswa dalam mengerjakan soal, suasana kelas pun tidak terlalu gaduh dibandingkan dengan siklus I.

c) Kegiatan Akhir

Setelah waktu untuk mengerjakan habis, guru meminta siswa mengumpulkan lembar jawabannya dan kembali ke tempat masing-masing. Guru mengakhiri pelajaran dengan salam dan mengingatkan siswa untuk selalu giat belajar serta mempersiapkan diri dalam presentasi besok.

2) Pertemuan kedua

Pertemuan kedua pada siklus II dilaksanakan pada hari Selasa, 29 Mei 2012. Kegiatan dilaksanakan sesuai dengan RPP yang telah dibuat terdiri dari tiga kegiatan:

a) Kegiatan Awal

Kegiatan dimulai dengan guru mengucapkan salam dan absensi siswa serta mengingatkan siswa tentangtujuan pembelajaran yang harus dicapai.

b) Kegiatan Inti

Seperti pada siklus I, siswa diminta berkumpul dengan kelompoknya dan guru membagikan lembar jawaban siswa serta mediabangun ruang sisi datar. Guru memanggil perwakilan kelompok secara acak untuk mempresentasikan hasil kerja kelompoknya pada pertemuan lalu. Setelah selesai mempresentasikan, kelompok lain diberi 
kesempatan untuk menanggapi hasil presentasi tadi. Guru memberikan tambahan jawaban sebagai pelengkap jawaban siswa.

c) Kegiatan Akhir

Kegiatan akhir dimulai dengan pemberian soal tes secara individu (tes akhir tindakan siklus II) untuk mengetahui tingkat pemahaman masing-masing individu. Setelah selesai siswa diminta untuk mengumpulkan hasil jawabannya dan kembali ke tempat masing-masing. Guru melakukan evaluasi dan memberikan bintang penghargaan kepada siswa yang mendapat niali sempurna tau tertinggi. Guru bersama siswa membuat kesimpulan tentang materi yang telah dipelajari dan berpesan untuk selalu giat belajar. Kegiatan pembelajaran diakhiri dengan ucapan salam serta soal kuis sebelum pulang.

3) Pertemuan ketiga

Pertemuan ketiga pada siklus II dilaksanakan tidak sesuai dengan jadwal karena kegiatan UAS diajukan pada minggu pertama bulan Juni. Rencana awal pada hari Selasa 5 Juni 2012 berubah menjadi hari Jum'at tanggal 1 Juni 2012 dengan mengambil jam pelajaran lain.

a) Kegiatan Awal

Guru memulai pelajaran dengan melakukan aktivitas sehari-hari yaitu dengan mengucapkan salam dan absensi siswa.

b) Kegiatan Inti

Guru membacakan semua hasil ulangan baik pada siklus I maupun siklus II. Guru memberikan hadiah kepada siswa yang mendapatkan bintang penghargaan terbanyak. Dan memberikan hadiah kepada kelompok yang nilainya tertinggi.

c) Kegiatan Akhir

Selanjutnya peneliti memberikan kata-kata perpisahan dengan member pesan dan kesan serta meminta maaf apabila selama mengajar, peneliti mempunyai kesalahan kepada siswa. Kegiatan diakhiri dengan salam.

c. Hasil Observasi

Pengamatan dilakukan oleh dua orang pengamat yang sama pada siklus I yaitu ibu Nurhayati, S.Pd sebagai pengamat 1 bertugas mengamati semua aktivitas guru dan bapak Subur Kasih, S.Pd sebagai pengamat 2, bertugas mengamati semua aktivitas siswa selama pembelajaran berlangsung. Pengamatan dilakukan dengan menggunakan pedoman observasi yang telah disediakan oleh peneliti.

Secara umum kegiatan peneliti sudah sesuai dengan rencana yang ditetapkan. Skor yang diperoleh dari pengamatan tentang aktivitas guru adalah 48, sedangkan skor maksimal adalah 50 . Sehingga nilai yang diperoleh rata-rata adalah $\frac{48}{50} \times 100 \%=96 \%$. Sesuai taraf keberhasilan yang ditetapkan, maka taraf keberhasilan aktivitas peneliti (guru) berada pada kategori sangat baik.

d. Hasil Catatan Lapangan

Beberapa hal yang sempat dicatat oleh peneliti dan pengamat pada kegiatan siklus II adalah sebagai berikut:

1) Siswa sudah bisa beradaptasi dengan guru dan teman kelompoknya 
2) Siswa bisa bertanggungjawab terhadap tugas masing-masing dan tidak mengandalkan jawaban teman sebelum berusaha menemukan jawabannya sendiri

3) Siswa telah menggunakan media sesuai kegunaannya

4) Siswa mulai percaya diri dan berani mengajukan pertanyaan dan pendapat dalam penyampaian materi

e. Hasil Tes Siswa

Berdasarkan hasil tes akhir siswa pada siklus II ini diurutkan berdasarkan nilai tertinggi ke nilai terendah yang dapat dilihat pada tabel berikut ini:

$$
\mathrm{NP}=\frac{\mathrm{R}}{\mathrm{SM}} \mathrm{X} 100=\frac{2174}{2500} \mathrm{X} 100=86,96
$$

Berdasarkan hasil tes akhir siklus II menunjukkan bahwa hasil tes siswa berkriteria sangat baik, hal ini menunjukkan bahwa terjadi peningkatan pemahaman pada siswa serta terjadi peningkatan hasil belajar yaitu nilai rata-rata siklus II adalah 86,96. Sedangkan nilai rata-rata tes siklus I adalah 72,56. Pada siklus II ada 19 siswa yang tuntas belajar dari 25 siswa.

Berdasarkan nilai akhir siklus II ini akan digunakan sebagai acuan dalam pemberian penghargaan kelompok. Poin peningkatan individual diperoleh dari poin yang dikumpulkan berdasarkan skor tes awal dan nilai tes siklus II, diperoleh hasil tes dihitung skor peningkatan individual berdasarkan perolehan skor tes awal dan skor tes akhir pada siklus II, berdasarkan skor peningkatan individual dihitung skor perkembangan (skor perbaikan) ada 16 siswa yang mendapat skor perbaikan 30, dan 1 siswa memperoleh skor perbaikan (skor perkembangan) 10. Untuk penghargaan kelompok (tim), kelompok II, III, IV dan V memperoleh penghargaan sebagai kelompok (tim) super, sedangkan kelompok I memperoleh penghargaan sebagai kelompok (tim) hebat.

f. Refleksi

Berdasarkan kegiatan analisis dan diskusi dengan teman sejawat terhadap hasil tes akhir dan hasil pengamatan / observasi pada siklus II, maka dapat diperoleh beberapa hal sebagai berikut:

1) Hasil belajar siswa berdasarkan nilai tes akhir tindakan menunjukkan peningkatan yang sangat baik dari tes sebelumnya. Hal ini menunjukkan bahwa pemahaman siswa terhadap materi pembelajaran semakin menningkat. Siswa juga tidak menggantungkan jawaban kepada temannya. Oleh karena itu, tidak perlu mengulang siklus untuk meningkatkan hasil belajar siswa

2) Aktivitas guru dan siswa telah menunjukkan tingkat keberhasilan pada kriteria sangat baik. Siswa sudah bisa beradaptasi dengan temannya, guru, model pembelajaran kooperatif yang baru. Oleh karena itu, tidak perlu dilakukan pengulangan siklus untuk aktivitas guru dan siswa

3) Kegiatan pembelajaran menunjukkan penggunaan waktu yang sudah sesuai rencana. Oleh sebab itu, tidak diperlukan pengulangan siklus.

Berdasarkan hasil refleksi dapat disimpulkan bahwa setelah pelaksanaan tindakan pada siklus II ini tidak diperlukan pengulangan siklus karena secara umum kegiatan pembelajaran telah berjalan sesuai rencana. Siswa telah dapat memahami materibangun ruang sisi datar yang dibuktikan lebih dari $75 \%$ siswa telah tuntas belajar. 
78 Priatina

\section{SIMPULAN}

Berdasarkan hasil analisis data dan pembahasan dapat diambil kesimpulan bahwa penerapan model pembelajaran kooperatif tipe STAD dalam materi Bangun Ruang Sisi Datar dapat digunakan dalam upaya meningkatkan hasil belajar siswa kelas VIII A SMP Islam Terpadu At-Taufiq Depok, terbukti dengan 19 siswa tuntas dari 25 siswa dengaan rata-rata 86,96.

\section{DAFTAR RUJUKAN}

Purwanto, Ngalim. 2004. Prinsip-Prinsip dan Teknik Evaluasi Pengajaran, Bandung: Remaja Rosdakarya. Eman, Suherman, et.all. 2003. Strategi Pembelajaran Matematika Kontemporer, Bandung: Fakultas Pendidikan Matematika dan IPA Universitas Pendidikan Indonesia.

2009. Undang-Undang RI No. 20 Tahun 2003 Tentang Sistem Pendidikan Nasional, Jakarta: Sinar Grafida. 